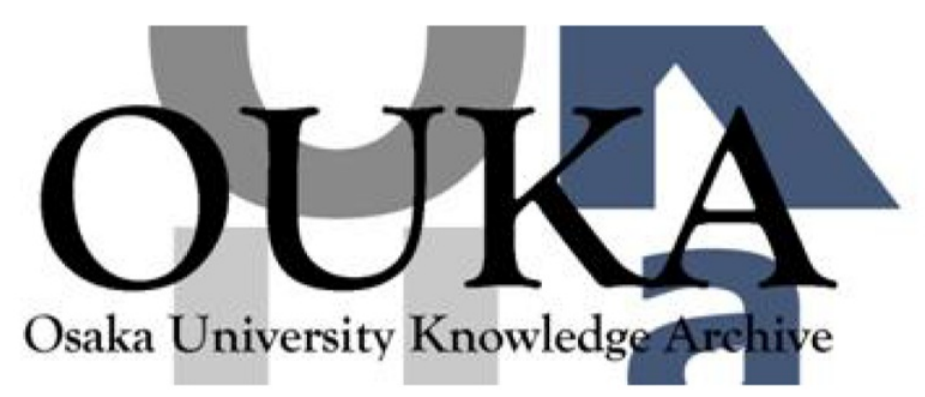

\begin{tabular}{|c|l|}
\hline Title & $\begin{array}{l}\text { Synthesis of 2, 7,12, 17-tetraary L-3,8, 13, 18- } \\
\text { tetranitroporphyrins; electronic effects on } \\
\text { aggregation properties of porphyrins }\end{array}$ \\
\hline Author(s) & $\begin{array}{l}\text { Ono, Noboru; Muratani, Emiko; Fumoto, Yumiko et } \\
\text { al. }\end{array}$ \\
\hline Citation & $\begin{array}{l}\text { JOURNAL OF THE CHEMICAL SOCIETY-PERKIN } \\
\text { TRANSACTIONS 1. 21 p. 3819-p.3824 }\end{array}$ \\
\hline Issue Date & $1998-11-21$ \\
\hline oaire:version & VoR \\
\hline URL & https://hdl. handle. net/11094/3141 \\
\hline rights & \\
\hline Note & \\
\hline
\end{tabular}

Osaka University Knowledge Archive : OUKA

https://ir. Library. osaka-u. ac. jp/

Osaka University 


\title{
Synthesis of 2,7,12,17-tetraaryl-3,8,13,18-tetranitroporphyrins; electronic effects on aggregation properties of porphyrins
}

\author{
Noboru Ono, ${ }^{* a}$ Emiko Muratani, ${ }^{a}$ Yumiko Fumoto, ${ }^{a}$ Takuji Ogawa ${ }^{a}$ and Kunihiko Tazima ${ }^{b}$ \\ ${ }^{a}$ Department of Chemistry, Faculty of Science, Ehime University, Matsuyama 790, Japan \\ ${ }^{b}$ Department of Polymer Science and Technology, Kyoto Institute of Technology, Matsugasaki, \\ Kyoto 606, Japan
}

Received (in Cambridge) 14th July 1998, Accepted 21st September 1998

\begin{abstract}
Novel porphyrins substituted with aryl and nitro substituents at the $\beta$-position were prepared by the tetramerization of 2-hydroxymethyl-3-aryl-4-nitropyrroles. Aggregation properties of these porphyrins are investigated by means of UV-VIS, ${ }^{1} \mathrm{H}-\mathrm{NMR}$ and EPR spectroscopy. Porphyrin 4a substituted with 4-methoxyphenyl and nitro groups was found to form a strong cofacial aggregate in solution $\left(K=900-1300 \mathrm{dm}^{3} \mathrm{~mol}^{-1}\right)$. The extent of aggregation decreases in the following order: porphyrin $\mathbf{4 a}$ (nitro and 4-methoxyphenyl substituents) $>\mathbf{4 b}$ (nitro and phenyl substituents) $>$ TMTP (methyl and phenyl substituents) > OEP (ethyl substituents). EPR spectra of $\mathrm{Cu}-\mathbf{4 a}$ support the dimer structure of $\mathbf{4 a}$, and the distance between two porphyrins is estimated to be about $4 \AA$.
\end{abstract}

\begin{abstract}
Nitroporphyrins are important because of their reactivity, ${ }^{1,2}$ altered electronic properties, ${ }^{3}$ aggregation properties, ${ }^{4}$ and use as non-linear optical materials. ${ }^{5}$ For example, Crossley and his co-workers have reported that the reaction of nitroporphyrins with alkoxides, amines or Grignard reagents provides a new method for the preparation of alkoxy-, amino- or alkylsubstituted porphyrins. ${ }^{1}$ The reaction of nitroporphyrins with the carbanion derived from active methylene compounds such as malononitrile or isocyanoacetate provides a new synthetic route to dihydroporphyrins or pyrroloporphyrins. ${ }^{2}$ The electronic properties of porphyrins are effectively altered by the presence of a strong electron withdrawing nitro group. ${ }^{3}$ In an extreme case, zinc and nickel $\beta$-heptanitroporphyrins form air-stable $\pi$-anion radicals by electrochemical reduction. ${ }^{3}$ Aggregation effects have been observed in porphyrins and related compounds, and aggregation appears to be most prominent in porphyrins bearing strongly electron withdrawing groups at either the meso- or $\beta$-positions. Thus, nitroporphyrins may provide important models for the study of porphyrin aggregation. ${ }^{4}$ Although a number of nitroporphyrins have been prepared by the nitration of porphyrins, ${ }^{6}$ this method is severely limited by the lack of regioselective control in the production of the desired nitroporphyrin. This paper reports a new approach to meso-unsubstituted- $\beta$-nitroporphyrins $\mathbf{4}$ by tetramerization of $\beta$-nitropyrroles, which cannot be prepared by the ordinary nitration method. Porphyrins $\mathbf{4}$ are interesting because they have four nitro and four aryl groups at alternate positions. Aggregation of such porphyrins may provide an important strategy for making supramolecular porphyrin arrays via selfassembly of porphyrins. Therefore, the aggregation properties of nitroporphyrins $\mathbf{4}$ were studied by means of UV-VIS, ${ }^{1} \mathrm{H}$ NMR and EPR spectroscopy and were compared with those of other related nitro-free porphyrins.
\end{abstract}

\section{Results and discussion}

\section{(1) Synthesis}

The route used for the preparation of 2,7,12,17-tetraaryl3,8,13,18-tetranitroporphyrins 4 is shown in Scheme 1. The requisite $\beta$-nitropyrroles (1) were prepared by the reaction of nitrostyrenes with tosylmethyl isocyanide (TosMIC). ${ }^{8}$ The reaction of 1 with dimethoxymethane and $p-\mathrm{TsOH}$ in benzene at
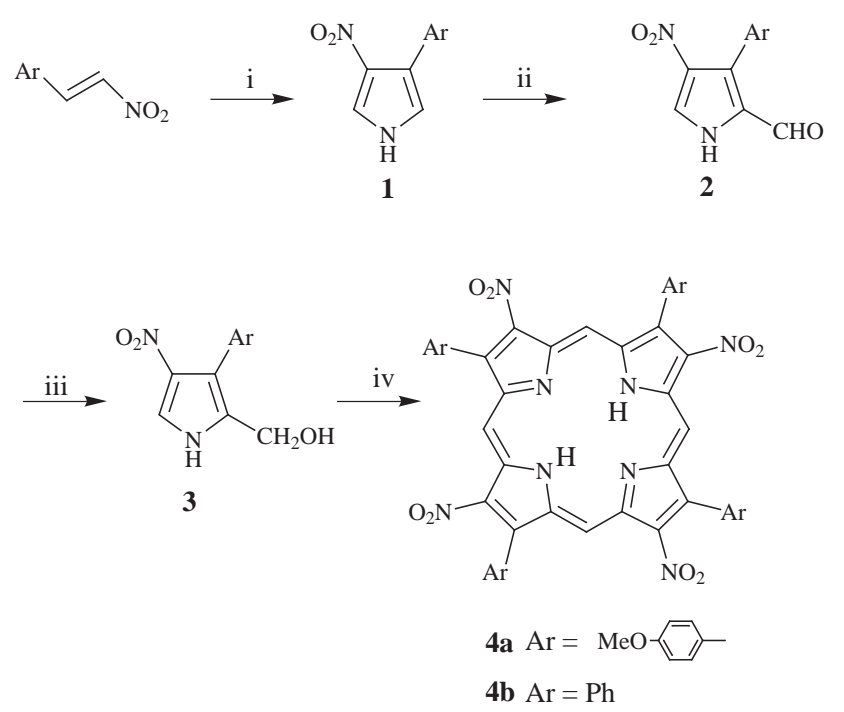

Scheme 1 Reagents and conditions: i, TosMIC, $\mathrm{NaH}$; ii, $\mathrm{POCl}_{3}, \mathrm{DMF}$; iii, $\mathrm{NaBH}_{4}$; iv, $p$-TsOH, $\mathrm{Zn}(\mathrm{OAc})_{2}$, chloranil; then $\mathrm{HCl}$.

$80{ }^{\circ} \mathrm{C}$ followed by oxidation gave a mixture of regioisomers of tetraaryl-tetranitroporphyrin in about $1 \%$ yield. The mesoproton portion of the ${ }^{1} \mathrm{H}-\mathrm{NMR}$ spectrum of the mixture of nitroporphyrins thus obtained is shown in Fig. 1(b), where complicated resonances are observed. This is explained by the presence of four regioisomers. The reaction of $\mathbf{1}$ with aromatic aldehydes did not give the desired porphyrins due to the low reactivity of $\mathbf{1}$. Therefore, we employed another tetramerization reaction developed by Ogoshi and our group for the synthesis of porphyrins with electron withdrawing groups. ${ }^{8}$ Formylation of $\mathbf{1}$ followed by reduction with $\mathrm{NaBH}_{4}$ gave 2-hydroxymethylpyrroles 3, which were reactive enough to give porphyrins 4 . Porphyrin 4a $\left(\mathrm{Ar}=p-\mathrm{MeOC}_{6} \mathrm{H}_{4}\right)$ and $\mathbf{4 b}(\mathrm{Ar}=\mathrm{Ph})$ were prepared in $5-10 \%$ yield by treatment with $p$-TsOH and subsequent oxidation in the presence of zinc acetate. Zinc acetate acts as an effective template to improve the yield of $\mathbf{Z n - 4 a}$, and the zinc metal is finally removed on treatment with acid to give 4a. The ${ }^{1} \mathrm{H}-\mathrm{NMR}$ spectrum of the meso protons of the porphyrin prepared by this method is shown in Fig. 1(a), where the meso protons are observed as a singlet. Type 1 porphyrins 4 as 
Table 1 Absorption spectra of $\mathbf{4 a}, \mathbf{4 b}$ and other porphyrins

\begin{tabular}{llll}
\hline Porphyrin $^{a}$ & Solvent & $\lambda_{\max }\left(\varepsilon / 10^{4} \mathrm{dm}^{3} \mathrm{~mol}^{-1} \mathrm{~cm}^{-1}\right)$ & $w_{1 / 2} / \mathrm{nm}^{b}$ \\
\hline $\mathbf{4 a}$ & $\mathrm{CHCl}_{3}$ & $470(5.6) 551(1.9) 592(0.68) 616(0.63) 681(0.35)$ & 78 \\
$\mathrm{Cu}-\mathbf{4 a}$ & $\mathrm{DMF}$ & $477(5.5) 568(1.2) 627(1.2)$ & 56 \\
$\mathbf{C u}-\mathbf{4 a}$ & $\mathrm{CHCl}$ & $464(5.6) 575(1.1) 620(1.2)$ & 33 \\
$\mathbf{4 b}$ & $\mathrm{CHCl}$ & $457(11) 546(3.6) 591(1.1) 622(1.0) 682(0.75)$ & 32 \\
$\mathbf{C u}-\mathbf{4 b}$ & $\mathrm{DMF}_{3}$ & $453(11) 570(2.2) 627(2.0)$ & 15 \\
$\mathrm{Cu}-\mathbf{4 b}$ & $\mathrm{CHCl}_{3}$ & $453(1.2) 567(2.1) 608(2.0)$ & 10 \\
TMTP & $\mathrm{CHCl}_{3}$ & $406(20) 502(1.7) 536(1.2) 570(0.87) 622(0.57)$ & 10
\end{tabular}

${ }^{a}$ TMTP: 2,7,12,17-Tetramethyl-3,8,13,18-tetraphenylporphyrin; OEP: 2,3,7,8,12,13,17,18-octaethylporphyrin. The concentration of the porphyrins was held at $1.0 \times 10^{-5} \mathrm{~mol} \mathrm{dm}{ }^{-3} \cdot{ }^{b} w_{1 / 2}=$ The half width of the Soret band.
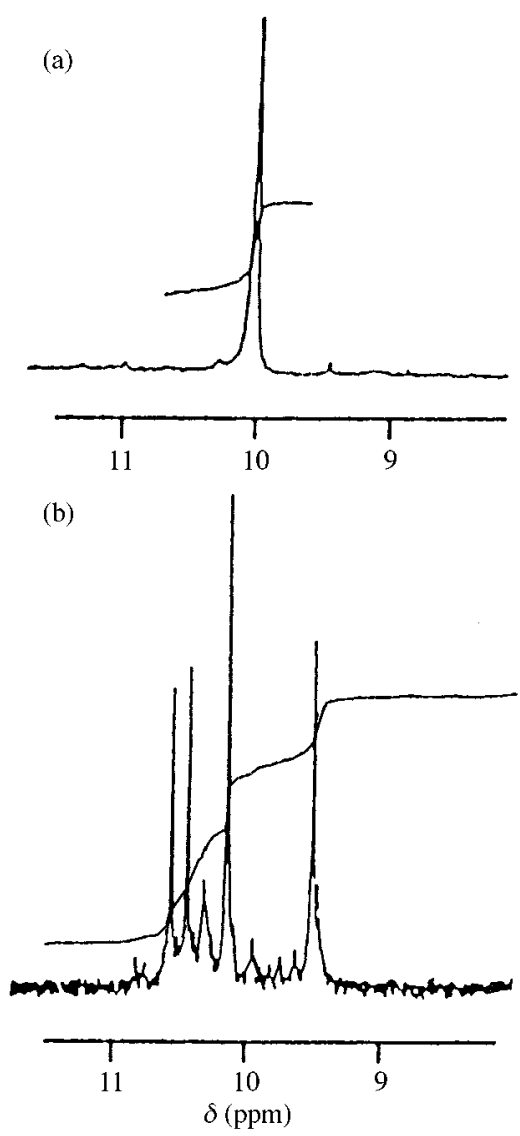

Fig. $1{ }^{1} \mathrm{H}$-NMR spectra of the meso protons of $4 \mathbf{a}$; (a) preparation according to Scheme 1 , (b) reaction of 1 with $\mathrm{CH}_{2}(\mathrm{OMe})_{2}$.

illustrated in Scheme 1 are formed selectively via tetramerization of $\mathbf{3}$ as shown in Fig. 1, isomeric purity is estimated by NMR analysis and is not greater than $95 \%$.

The absorption spectra of these porphyrins and their metal complexes are shown in Fig. 2. Absorption maxima $\left(\lambda_{\max }\right)$ and molar extinction coefficients $(\varepsilon)$ are summarized in Table 1 . The Soret and Q bands of $\mathbf{4}$ are shifted to the longer wavelengths and are very broad compared to those of 2,7,12,17-tetramethyl3,8,13,18-tetraphenylporphyrin (TMTP) ${ }^{9}$ and 2,3,7,8,12,13, 17,18-octaethylporphyrin (OEP). The broad spectra suggest that $\mathbf{4 a}$ and $\mathbf{4 b}$ form aggregates even at a low concentration of $10^{-5} \mathrm{~mol} \mathrm{dm}^{-3}$. Reasonably good linear relationships exist between the interplanar distance between the two porphyrin rings and the width of the UV-VIS Soret band. ${ }^{10}$ The halfwidth of the Soret band $\left(w_{1 / 2}\right)$ is a simple estimation of porphyrin aggregation. According to this estimation, the extent of aggregation is in the order of $\mathbf{4 a}>\mathbf{4 b}>$ TMTP. This is further confirmed by means of ${ }^{1} \mathrm{H}-\mathrm{NMR}$ and EPR experiments.

The redox potentials of the copper porphyrins were measured by the cyclic voltammetry $(\mathrm{CV})$ method. The $\mathrm{CV}$ studies
Table 2 Redox properties of metal porphyrins $4^{a}$

\begin{tabular}{llcccc}
\hline Porphyrin & $E_{1 / 2}^{\mathrm{ox}}(1)$ & $E_{1 / 2}^{\mathrm{ox}}(2)$ & $E_{1 / 2}^{\mathrm{re}}(1)$ & $E_{1 / 2}^{\mathrm{re}}(2)$ & $\Delta E_{1 / 2}(1)$ \\
\hline $\mathrm{Cu}-\mathbf{4 a}$ & 1.19 & & -0.61 & -1.10 & 1.80 \\
$\mathrm{Cu}-\mathbf{4 b}$ & 1.30 & & -0.58 & -1.06 & 1.88 \\
$\mathrm{CuTMTP}$ & 0.80 & 1.20 & -1.50 & & 2.30 \\
$\mathrm{CuOEP}$ & 0.66 & 1.18 & -1.71 & & 2.37 \\
${ }^{a} E / \mathrm{V}$ v $s . \mathrm{SCE}$ in $\mathrm{CH}_{2} \mathrm{Cl}_{2}, 0.2 \mathrm{M}$ TBAP. & &
\end{tabular}

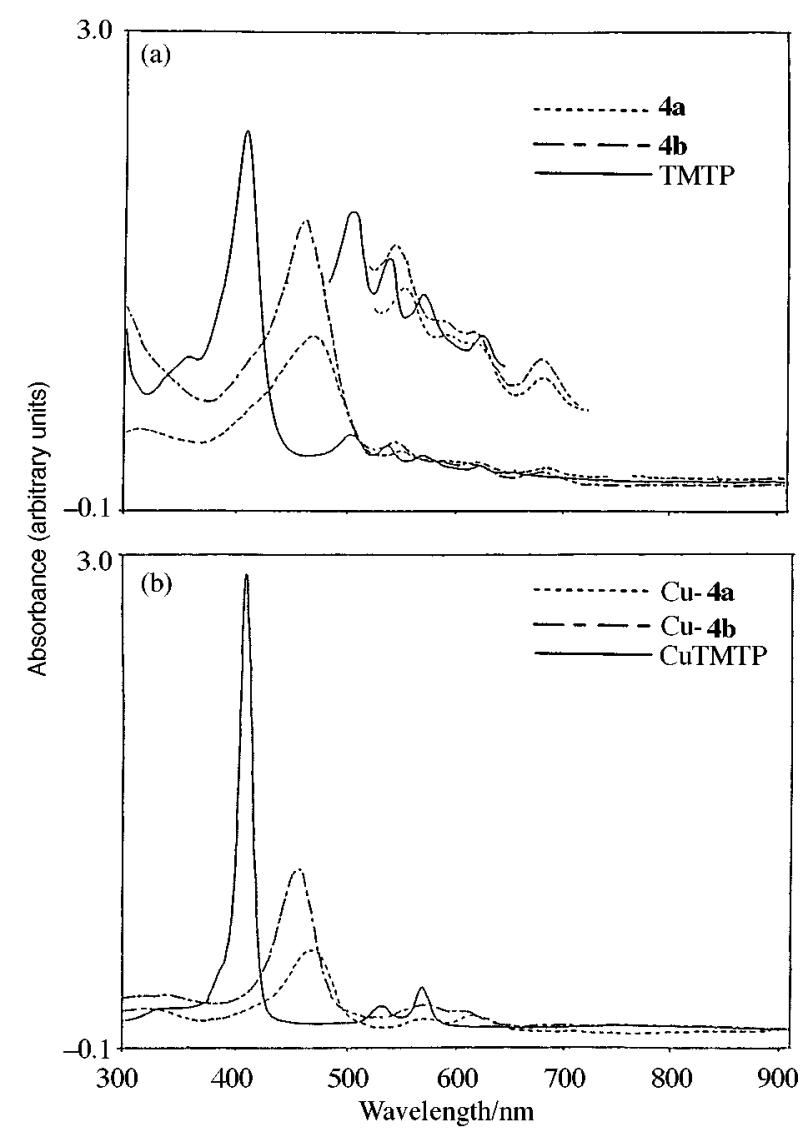

Fig. 2 Absorption spectra of porphyrins 4.

were performed on a $\mathrm{Pt}$ electrode using $\mathrm{CH}_{2} \mathrm{Cl}_{2}$ as the solvent and $0.2 \mathrm{M}$ tetrabutylammonium perchlorate (TBAP) as the supporting electrolyte. The redox potential data of $\mathrm{Cu}-\mathbf{4}$ are summarized in Table 2. The one-electron redox potentials of porphyrins reflect the energy levels of their HOMO and LUMO. The difference $\left(\Delta E_{1 / 2}\right)$ reflects the energy difference between HOMO and LUMO, which is normally $2.2-2.3 \mathrm{~V}$ for usual porphyrins. The introduction of four nitro groups lowers the LUMO and HOMO levels by $0.9-1.0 \mathrm{~V}$ and $0.5 \mathrm{~V}$, respectively. These values are in good agreement with those of known nitroporphyrins. ${ }^{3}$ Thus, $\Delta E$, namely the $\pi-\pi^{*}$ gap, for tetranitro- 


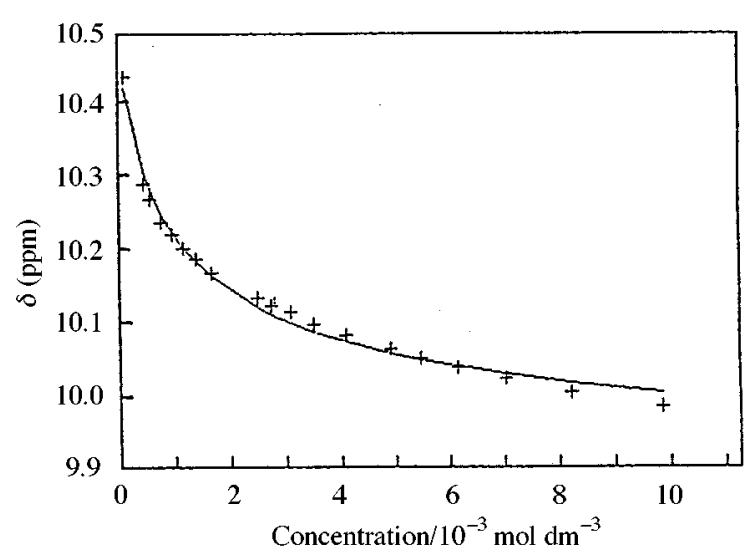

Fig. 3 Plot of ${ }^{1} \mathrm{H}$ chemical shift versus concentrations for the meso- $\mathrm{H}$ resonances of $\mathbf{4 a}$.

porphyrins $\mathbf{4}$ is smaller than that of other porphyrins which brings about the red shift of the UV-VIS spectra. This is due either to $\pi$-conjugation of the nitro group with the porphyrin rings or to aggregation of $\mathbf{4}$. Since electron deficient porphyrins are important because they are excellent catalysts in metalloporphyrin catalyzed oxygenation reactions, ${ }^{4}$ many electron deficient porphyrins have been prepared. Perfluoroalkylated porphyrins behave differently from 4 . Namely, the $\pi-\pi^{*}$ gap of perfluoroalkylated porphyrins is not affected by the introduction of the perfluoroalkyl substituents. ${ }^{11}$

\section{(2) Aggregation properties}

The aggregation properties of porphyrins are of central importance to understanding the chemistry of chlorophylls and metalloporphyrins, especially in relation to their important biological functions such as efficient electron transfer in the photosynthetic reaction center. ${ }^{12}$ The aggregation of porphyrins has been extensively studied in solution by NMR spectroscopy. ${ }^{13}$ The ${ }^{1} \mathrm{H}-\mathrm{NMR}$ spectra of $\mathbf{4 a}$ showed large complexation shifts as shown in Fig. 3 and Table 3. Similar shifts were also observed for $\mathbf{4 b} .{ }^{1} \mathrm{H}-\mathrm{NMR}$ measurements at different concentrations can be used to determine the dimerization constant, $K$, using the reported procedure. ${ }^{12}$ The chemical shifts of the monomers $\left(\delta_{\mathrm{m}}\right)$ and of the dimers $\left(\delta_{\mathrm{d}}\right)$ are estimated, and they are summarized in Table 4. By this method, $K$ was found to be 900 (from meso$\mathrm{H}$ change)-1300 (from $\mathrm{NH}$ change) and 90 (from meso-H change)-130 (from NH change) $\mathrm{dm}^{3} \mathrm{~mol}^{-1}$ for $\mathbf{4 a}$ and $\mathbf{4 b}$, respectively. The effect of the concentration of TMTP and OEP was also studied, and $K$ was evaluated from these experiments. Some chemical shifts at certain concentrations are shown in the Experimental section. Interestingly, the effect of concentration on the ${ }^{1} \mathrm{H}-\mathrm{NMR}$ chemical shifts was very small in these cases. Although $K$ for TMTP could be estimated to be 16 (from meso$\mathrm{H}$ change)-10 (from NH change) $\mathrm{dm}^{3} \mathrm{~mol}^{-1}$, no evidence of self-association was observed for OEP. The NH proton signals are shifted upfield for the cofacial dimers relative to the corresponding monomers. The magnitude of this shift $(\Delta \delta)$ is correlated with the distance between the two porphyrins. Namely, $\mathrm{P}-$ $\mathrm{P}=6.46+0.88 \Delta \delta \AA .{ }^{11}$ According to this equation, the distance between monomers in the dimers derived from $\mathbf{4 a}$ is estimated to be about $4 \AA$. Aggregation of alkyl substituted porphyrins such as OEP is negligible when they are present as free bases. Metal complexes of OEP and their radical cations form aggregates. ${ }^{14}$ TMTP shows greater aggregation than OEP but less than $4 \mathbf{a}$ and $\mathbf{4 b}$. Thus, aggregation is strongly enhanced by the introduction of a nitro group. As 4a has a symmetrical structure, cofacial dimers should be favored for the dimer structure.

EPR spectra of the copper complexes of these porphyrins were measured at $77 \mathrm{~K}$ (Fig. 4), and EPR parameters are summarized in Table 5. Both copper $(I=3 / 2)$ and nitrogen $(I=1)$

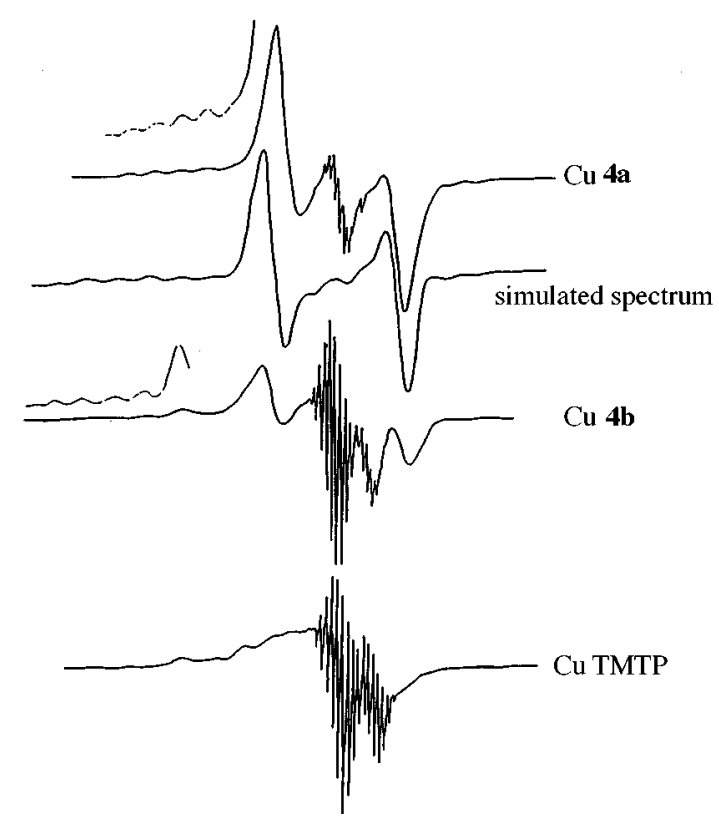

Fig. 4 EPR spectra in toluene at $77 \mathrm{~K}$.

hyperfine splittings are well-resolved for $\mathrm{Cu}-\mathrm{TMTP}$ which are typical of spectra for non-aggregated $\mathrm{Cu}$-porphyrins. ${ }^{14} \mathrm{On}$ the other hand, EPR spectra of $\mathrm{Cu}-\mathbf{4 a}$ are different from those of $\mathrm{Cu}-\mathrm{TMTP}$, where two strong perpendicular transitions, without nitrogen hyperfine splittings are observed in the $g=2$ region. This is typical of a triplet $(S=1)$ state with axial symmetry. In the case of $\mathrm{Cu}-\mathbf{4 b}$, mixed spectra derived from monomer and dimer were observed. In the triplet system, the electron spin is delocalized over both $\mathrm{Cu}$ (II) centers, causing a decrease in the $\mathrm{Cu}$ and $\mathrm{N}$ hyperfine splitting. The zero-field splitting parameter, $D$, was used to calculate the distance $R$ between the $\mathrm{Cu}(\mathrm{II})$ centers. ${ }^{14,15}$ The observed $\mathrm{Cu}-\mathrm{Cu}$ distance of $4.3 \AA$ is in good agreement with the reported value of the covalent linked dimers ${ }^{14}$ as well as those derived from noncovalent dimers. ${ }^{15}$ The geometry of the porphyrin-porphyrin interaction is also the subject of a recent study. In general porphyrins prefer to stack in an offset manner rather than with one molecule directly over another, and several types of interaction have been proposed. ${ }^{16}$ However, the aggregates of $4 \mathbf{a}$ may form cofacial dimers rather than slipped ones due to the symmetrical substituents of $\mathbf{4 a}$.

A new route to nitroporpyrins $\mathbf{4}$ has been found, and they and their metal complexes form cofacial aggregates in solution. As biologically active porphyrins usually occur as dimers, synthetic porphyrin dimers or aggregated dimers of porphyrins have been extensively studied. They are built up by a covalent bond, ${ }^{17}$ self assembly via electrostatic interaction between positively and negatively charged porphyrins ${ }^{15,18}$ or a hydrogen bonding interaction. ${ }^{19}$ They are the focus of much interest as model enzymes, model photosynthetic systems, and oxygen activators. ${ }^{20}$ In contrast to the cofacial aggregations of porphyrins studied so far, the cofacial aggregation of $\mathbf{4}$ takes place by spontaneous association of neutral porphyrins.

\section{Experimental}

${ }^{1} \mathrm{H}-\mathrm{NMR}$ spectra were recorded on a JEOL-JNM-GSX 270 spectrometer using tetramethylsilane as an internal standard. IR and UV-VIS spectra were obtained with Hitachi 270-30 and Shimadzu-2200 spectrometers, respectively. EPR spectra were recorded on a JES-ME-3X X-band spectrometer. FAB mass spectra of porphyrins were measured with a JEOL JMS-DX300 spectrometer; samples were dissolved in $\mathrm{CHCl}_{3}$ and $\mathrm{m}$ nitrobenzyl alcohol was used as the matrix. 
Table 3 Observed chemical shifts $[\delta(\mathrm{ppm})]$ for 4 a versus concentration $\left(10^{-3} \mathrm{~mol} \mathrm{dm}^{-3}\right)$

\begin{tabular}{|c|c|c|c|c|c|c|c|c|c|c|c|c|c|c|c|c|c|c|c|}
\hline Proton & 9.84 & 8.20 & 7.03 & 6.15 & 5.57 & 4.92 & 4.10 & 3.51 & 3.07 & 2.73 & 2.46 & 1.64 & 1.34 & 1.13 & 0.92 & 0.74 & 0.53 & 0.41 & 0.082 \\
\hline meso & 9.99 & 9.99 & 10.02 & 10.03 & 10.05 & 10.06 & 10.08 & 10.09 & 10.11 & 10.12 & 10.13 & 10.17 & 10.19 & 10.20 & 10.22 & 10.24 & 10.27 & 10.30 & 10.45 \\
\hline $\mathrm{H}_{\mathrm{a}}$ & 7.81 & 7.82 & 7.86 & 7.84 & 7.88 & 7.86 & 7.87 & 7.88 & 7.88 & 7.89 & 7.89 & 7.94 & 7.93 & 7.95 & 7.94 & 7.93 & 7.94 & 7.95 & 8.00 \\
\hline $\mathrm{H}_{\mathrm{b}}$ & 7.19 & 7.20 & 7.20 & 7.22 & 7.22 & 7.23 & 7.24 & 7.24 & 7.25 & 7.25 & 7.26 & 7.27 & 7.27 & 7.28 & 7.28 & 7.29 & 7.29 & 7.30 & 7.32 \\
\hline $\mathrm{OCH}_{3}$ & 4.13 & 4.13 & 4.13 & 4.13 & 4.13 & 4.13 & 4.13 & 4.13 & 4.13 & 4.13 & 4.13 & 4.12 & 4.12 & 4.12 & 4.12 & 4.12 & 4.11 & 4.11 & 4.09 \\
\hline NH & -6.19 & -6.15 & -6.10 & -6.05 & -6.01 & -5.94 & -5.89 & -5.83 & -5.79 & 5.81 & -5.64 & -5.56 & -5.59 & -5.32 & -5.31 & -5.11 & -4.95 & -4.84 & -4.14 \\
\hline
\end{tabular}


Table 4 Calculated equilibrium constants $(K)$ and monomer and dimer shifts $\left(\delta_{\mathrm{m}}, \delta_{\mathrm{d}}\right)$

\begin{tabular}{|c|c|c|c|c|c|c|c|c|}
\hline \multirow[b]{2}{*}{ Porphyrin } & \multicolumn{4}{|l|}{ meso-H } & \multicolumn{4}{|l|}{$\mathrm{NH}$} \\
\hline & $K / \mathrm{dm}^{3} \mathrm{~mol}^{-1}$ & $\delta_{\mathrm{m}}$ & $\delta_{\mathrm{d}}$ & $\Delta \delta$ & $K / \mathrm{dm}^{3} \mathrm{~mol}^{-1}$ & $\delta_{\mathrm{m}}$ & $\delta_{\mathrm{d}}$ & $\Delta \delta$ \\
\hline $4 a$ & 900 & 10.49 & 9.83 & 0.66 & 1300 & -3.70 & -6.75 & 3.05 \\
\hline $4 b$ & 90 & 10.75 & 9.84 & 0.91 & 130 & -2.70 & -6.32 & 3.62 \\
\hline TMTP & 16 & 10.09 & 9.95 & 0.14 & 10 & -3.51 & -4.10 & 0.59 \\
\hline OEP & 0 & 10.11 & 10.11 & 0 & 0 & -3.75 & -3.75 & 0 \\
\hline
\end{tabular}

Table 5 EPR parameters

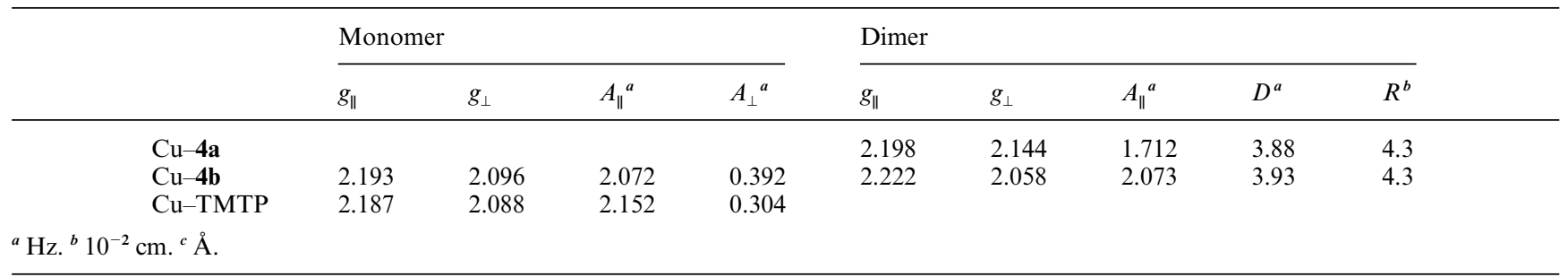

\section{3-Aryl-2-formyl-4-nitropyrroles}

They were prepared according to the procedure given in the literature. ${ }^{7}$

\section{Preparation of porphyrin 4a}

A mixture of 2-formyl-3-(4-methoxyphenyl)-4-nitropyrrole (2.5 $\mathrm{g}, 10 \mathrm{mmol})$ and $\mathrm{NaBH}_{4}(10 \mathrm{mmol})$ in THF $(25 \mathrm{ml})$ was stirred at room temperature for $8 \mathrm{~h}$, poured into water and extracted with $\mathrm{CH}_{2} \mathrm{Cl}_{2}(100 \mathrm{ml} \times 3)$. To the combined extracts were added toluene- $p$-sulfonic acid $(0.05 \mathrm{~g})$ and zinc acetate dihydrate (4.49 $\mathrm{g}, 20 \mathrm{mmol}$ ), and the resulting solution was stirred for $12 \mathrm{~h}$ at room temperature and then chloranil $(2.5 \mathrm{~g}, 10 \mathrm{mmol})$ was added. The mixture was refluxed for $8 \mathrm{~h}$, and then washed with $5 \%$ sodium hydrogen carbonate, and the organic layer was dried with anhydrous sodium carbonate. After evaporation, column chromatography of the residue (silica gel, $\mathrm{CH}_{2} \mathrm{Cl}_{2}$ ) and recrystallization from $\mathrm{CH}_{2} \mathrm{Cl}_{2}-\mathrm{MeOH}$ gave $\mathrm{Zn}-\mathbf{4 a}$ which was treated with $6 \mathrm{M} \mathrm{HCl}(10 \mathrm{ml})$ in $\mathrm{CH}_{2} \mathrm{Cl}_{2}(20 \mathrm{ml})$ at room temperature. The organic layer was evaporated to give $4 \mathrm{a}$ which was further purified by recrystallization from $\mathrm{CH}_{2} \mathrm{Cl}_{2}-\mathrm{MeOH}$ to give $4 \mathbf{a}(0.23 \mathrm{~g}, 10 \%$ yield $)$. The copper complex of $\mathbf{4 a}$ was prepared by treatment with copper acetate in $\mathrm{CH}_{2} \mathrm{Cl}_{2}-$ $\mathrm{MeOH}$. Porphyrin $\mathbf{4 b}$ was prepared in $8 \%$ yield by the same procedure.

4a: At a concentration of $9.84 \times 10^{-3} \mathrm{~mol} \mathrm{dm}^{-3}, \delta_{\mathrm{H}}\left(\mathrm{CDCl}_{3}\right)$ $9.99(\mathrm{~s}$, meso-H), $7.81(\mathrm{~d}, 8 \mathrm{H}), 7.19(\mathrm{~d}, 8 \mathrm{H}), 4.13(\mathrm{~s}, 12 \mathrm{H})$, $-6.19(\mathrm{~s}, \mathrm{NH})$; these chemical shifts are changed to $\delta_{\mathrm{H}}\left(\mathrm{CDCl}_{3}\right)$ $10.45,8.00,7.32,4.09,-4.14$ at a concentration of $0.082 \times 10^{-3}$ $\mathrm{mol} \mathrm{dm}{ }^{-3} ; v_{\max }(\mathrm{KBr}) / \mathrm{cm}^{-1} 3420,1510,1330 ; \mathrm{m} / \mathrm{z}$ (FAB) 914.8 $\left(\mathrm{M}^{+}, \mathrm{C}_{48} \mathrm{H}_{34} \mathrm{~N}_{8} \mathrm{O}_{12}\right.$ requires 914.843), $1829\left(2 \mathrm{M}^{+}\right)$(Found: $\mathrm{C}$, 62.67; H, 3.83; N, 3.53. Calc. for $\mathrm{C}_{48} \mathrm{H}_{34} \mathrm{~N}_{8} \mathrm{O}_{12}$ : C, 63.02; $\mathrm{H}$, 3.75; N, 12.25\%). $\mathrm{Cu}-4 \mathrm{a}: \mathrm{m} / z(\mathrm{FAB}) 976\left(\mathrm{M}^{+}, \mathrm{C}_{48} \mathrm{H}_{32} \mathrm{~N}_{8} \mathrm{O}_{12} \mathrm{Cu}\right.$ requires 976.366$), 1953\left(2 \mathrm{M}^{+}\right)$.

4b: At a concentration of $2.34 \times 10^{-3} \mathrm{~mol} \mathrm{dm}^{-3}, \delta_{\mathrm{H}}\left(\mathrm{CDCl}_{3}\right)$ $10.53(\mathrm{~s}$, meso-H), $8.01(\mathrm{Ph}), 7.82(\mathrm{Ph}),-3.77(\mathrm{~s}, \mathrm{NH})$; these chemical shifts are changed to $\delta_{\mathrm{H}} 10.70,7.81,7.19,-2.97$ at $0.33 \times 10^{-3} \mathrm{~mol} \mathrm{dm}{ }^{-3} ; v_{\max }(\mathrm{KBr}) / \mathrm{cm}^{-1} 3420,1510,1330 ; \mathrm{m} / \mathrm{z}$ (FAB) $794\left(\mathrm{M}^{+}, \mathrm{C}_{44} \mathrm{H}_{26} \mathrm{~N}_{8} \mathrm{O}_{8}\right.$ requires 794.75) (Found: C, 66.15; $\mathrm{H}, 3.38 ; \mathrm{N}, 13.76$. Calc. for $\mathrm{C}_{44} \mathrm{H}_{26} \mathrm{~N}_{8} \mathrm{O}_{8}: \mathrm{C}, 66.49 ; \mathrm{H}, 3.30$; $\mathrm{N}, 14.10 \%)$. Cu-4b: $m / z(\mathrm{FAB}) 856.14\left(\mathrm{M}^{+}, \mathrm{C}_{44} \mathrm{H}_{24} \mathrm{~N}_{8} \mathrm{O}_{8} \mathrm{Cu}\right.$ requires 856.27$)$.

\section{${ }^{1}$ H-NMR measurement}

Chemical shifts were determined at various concentrations of the porphyrins. The data for $\mathbf{4 a}$ are shown in Table 3. Selected data for the meso and NH protons of $\mathbf{4 b}$, TMTP and OEP are shown in Table 6. Equilibrium constants $(K)$ were determined
Table 6 Observed proton chemical shifts versus concentration

\begin{tabular}{lcll}
\hline \multirow{2}{*}{ Porphyrin } & $\begin{array}{l}\text { Concentration/ } \\
10^{-3} \mathrm{~mol} \mathrm{dm}^{-3}\end{array}$ & meso-H $\delta(\mathrm{ppm})$ & $\mathrm{NH} \delta(\mathrm{ppm})$ \\
\hline $\mathbf{4 b}$ & 2.36 & 10.53 & -3.77 \\
& 1.69 & 10.57 & -3.61 \\
& 1.05 & 10.62 & -3.38 \\
& 0.75 & 10.65 & -3.21 \\
& 0.58 & 10.67 & -3.14 \\
TMTP & 0.33 & 10.71 & -2.97 \\
& 17.51 & 10.05 & -3.63 \\
& 8.01 & 10.06 & -3.59 \\
& 5.09 & 10.07 & -3.51 \\
& 2.91 & 10.07 & -3.54 \\
& 1.09 & 10.07 & -3.47 \\
OEP & 0.68 & 10.09 & -3.54 \\
& 0.37 & 10.09 & -3.54 \\
& 19.82 & 10.11 & -3.74 \\
& 9.91 & 10.10 & -3.75 \\
& 4.95 & 10.11 & -3.75 \\
& 0.47 & 10.11 & -3.75 \\
\hline
\end{tabular}

from these data using the same procedure as given in the literature. ${ }^{13}$ The results are summarized in Table 4 .

\section{Acknowledgements}

This work was supported by a Grant-in-Aid for Scientific Research from the Ministry of Education, Science, Sports and Culture, Japan.

\section{References}

1 L. C. Gong and D. Dolphin, Can. J. Chem., 1985, 63, 406; J. E. Baldwin, M. J. Crossley and J. DeBernardis, Tetrahedron, 1982, 38, 685; M. J. Crossley and L. G. King, J. Chem. Soc., Perkin Trans. 1, 1996, 1251; M. J. Crossley, L. G. King, I. A. Newsom and C. S. Sheeham, J. Chem. Soc., Perkin Trans. 1, 1996, 2675; M. J. Crossley, L. G. King and J. L. Simpson, J. Chem. Soc., Perkin Trans. 1, 1997, 3087; M. J. Crossley, M. M. Harding and C. W. Tansey, J. Org. Chem., 1994, 59, 4433; M. J. Crossley and L. G. King, J. Org. Chem., 1993, 58, 4370 .

2 L. Jaquinod, C. Gros, M. M. Olmstead, M. Antolovich and K. M. Smith, Chem. Commun., 1996, 1475; L. Jaquinod, C. Gros, R. G. Khoury and K. M. Smith, Chem. Commun., 1996, 2581; C. P. Gros, L. Jaquinod, R. G. Khoury, M. M. Olmstead and K. M. Smith, J. Porphyrins Phthalocyanines, 1997, 1, 201 and references therein.

3 K. Ozette, P. Leduc, M. Palacio, J. F. Bartoli, K. M. Barkiga, J. Fajor, P. Battioni and D. Mansuy, J. Am. Chem. Soc., 1997, 119, 6442; P. G. Gassman, A. Ghosh and J. Almlof, J. Am. Chem. Soc., 1992, 114, 9990 and references therein. Electron deficient porphyrins are useful as efficient catalysts for the oxidation of alkanes, see: 
D. Dolphin, T. G. Taylor and L. Y. Xie, Acc. Chem. Res., 1997, 30, 251.

4 M. O. Senge, C. W. Eigenbrot, T. D. Brennan, J. Sbusta, W. R. Scheidt and K. M. Smith, Inorg. Chem., 1993, 32, 3134; M. O. Senge and K. M. Smith, J. Chem. Soc., Chem. Commun., 1994, 923.

5 K. S. Suslick, C. T. Chen, G. R. Meredith and L. T. Cheng, J. Am. Chem. Soc., 1992, 114, 6928; A. Sastre, T. Torres, M. A Diaz-Garcia, F. Agullo-Lopez, C. Dhenaut, S. Brasselet, I. Ledoux and J. Xyss, J. Am. Chem. Soc., 1996, 118, 2746; S. M. LeCours, H.-W. Guan, S. T. DiMango, C. H. Wang and M. J. Therien, J. Am. Chem. Soc., 1996, 118, 1497; A. Sen and V. Krishnan, Tetrahedron Lett., 1996, 37, 5421; L. Karki, F. W. Vance, J. H. Hupp, S. M. LeCours and M. J. Therien, J. Am. Chem. Soc., 1998, 120, 2606.

6 R. Bonnett and G. F. Stephenson, J. Org. Chem., 1965, 30, 2791; K. M. Smith, G. H. Barnett, B. Evans and Z. Martynenko, J. Am. Chem. Soc., 1979, 101, 5953; L. C. Gong and D. Dolphin, Can. J. Chem., 1985, 63, 401

7 N. Ono, E. Muratani and T. Ogawa, J. Heterocycl. Chem., 1991, 28, 2053; D. van Leusen, E. Flentge and A. M. van Leusen, Tetrahedron, 1991, 47, 4639.

8 K. Aoyagi, H. Toi, Y. Aoyama and H. Ogoshi, Chem. Lett., 1988, 1891; N. Ono, H. Kawamura and K. Maruyama, Bull. Chem. Soc Jpn., 1989, 62, 3386; N. Ono, K. Sugi and T. Ogawa, Chem. Express, 1991, 869; K. Sugiura, M. R. Kumar, T. K. Chandrashekar and Y. Sakata, Chem. Lett. 1997, 291.

9 C. K. Chang and N. Bag, J. Org. Chem., 1996, 60, 7030

10 R. Karaman, O. Almarsson and T. C. Bruice, J. Org. Chem., 1992, 57, 1555.

11 J. G. Goll, K. T. Moore, A. Ghosh and M. J. Therien, J. Am. Chem Soc., 1996, 118, 8344.

12 J. Deisenhofer and H. Michel, Science, 1989, 245, 1463; I. W. White, in The Porphyrins, ed. D. Dolphin, Academic Press, New York, 1978, vol. V, p. 303; R. K. Clayton and W. R. Sistrom, The Photosynthetic Bacteria, Plenum Press, New York, 1978; R. J. Abraham, F. Eivazi, H. Perason and K. M. Smith, J. Chem. Soc., Chem. Commun., 1976, 698.
13 I. Horman and B. Dreux, Helv. Chim. Acta, 1984, 67, 754; R. J. Abraham, R. E. Rowan, K. E. Mansfield and K. M. Smith, J. Chem. Soc., Perkin Trans. 2, 1991, 515 and references therein.

14 S. S. Waton, G. R. Eaton and C. K. Chang, J. Am. Chem. Soc., 1985, $\mathbf{1 0 7}, 3177$.

15 V. Thanabal and V. Krishnan, J. Am. Chem. Soc., 1982, 104, 3643; M. C. Feiters, M. C. T. Fyfe, M. V. M. Diaz, S. Menzer, R. J. M. Nolte, J. F. Stoddart, P. J. M. van Kan and D. J. Williams, J. Am. Chem. Soc., 1997, 119, 8119.

16 P. Leighton, J. A. Cowan, R. J. Abraham and J. K. M. Sanders, J. Org. Chem., 1988, 53, 733; C. Endisch, J. H. Fuhrhop, J. Buschmann, P. Luger and U. Siggel, J. Am. Chem. Soc., 1996, 118, 6671 and references therein.

17 J. P. Collman, C. S. Bencosme, C. E. Barren and B. D. Miller, J. Am. Chem. Soc., 1983, 105, 2704; I. Abdalmuhdi and C. K. Chang, J. Org. Chem., 1985, 50, 411; J. P. Collman, D. A. Tyvoll, L. L. Chang and H. T. Fish, J. Org. Chem., 1995, 60, 1926 and many references therein.

18 E. Ojadi, R. Selzer and H. Linschitz, J. Am. Chem. Soc., 1985, 107, 7783; J. K. Ribo, J. Crusats, J. A. Farrera and M. L. Valero, J. Chem. Soc., Chem. Commun., 1994, 681.

19 T. Aida, A. Takemura, M. Fuse and S. Inoue, J. Chem. Soc, Chem. Commun., 1988, 391; R. H. Jin, S. Aoki and K. Shima, Chem. Commun., 1996, 1939; Y. Kuroda, A. Kawashima, T. Urai and H. Ogoshi, Tetrahedron Lett., 1995, 36, 8449; amphiphilic porphyrins form aggregates in water, A. P. H. J. Schenning, M. C. Feiters and R. J. M. Nolte, Tetrahedron Lett., 1993, 34, 7081.

20 Recent review: J. P. Collman, P. S. Wagenknecht and J. F. Hutchison, Angew. Chem., Int. Ed. Engl., 1994, 33, 1537. Covalent porphyrin dimers have been employed as molecular catalysts for multi-electron redox reactions, but recently ionic porphyrin dimers have also been used for this purpose, see, F. G'Souza, Y. Y. Hsich and G. R. Deviprasad, Chem. Commun., 1998, 1027.

Paper $8 / 05471 \mathrm{~A}$ 